\title{
Pandemic and the state
}

\author{
Swagato Sarkar ${ }^{1}$ (D)
}

Accepted: 12 November 2020 / Published online: 25 December 2020

(c) Institute for Social and Economic Change 2020

\begin{abstract}
It has been argued the pandemic has brought back the state. The discussions on this return of the state have been concentrated, so far, around familiar themes: trade-off between freedom-privacy and security with the expansion of control and surveillance of our bodies by the state, efficiency-competency of the state in containing the spread of the virus, and exclusion of marginalised peoples from healthcare facilities and sacrifice of older people in the process of rational allocation of critical care. In this short essay, I will explore and engage with these debates, and enquire what the pandemic control measures and outcomes tell us about present nature of the Indian state.
\end{abstract}

Keywords COVID $\cdot$ State $\cdot$ Public policy $\cdot$ Power $\cdot$ State capacity $\cdot$ Bureaucracy

The COVID-19 pandemic has been described as a Black Swan event, which could not be predicted. In contrast, the Financial Crisis of 2008 was a shock induced by market failure, and civil wars are caused by state failure. Natural disasters such as famine, flood or cyclone cause localised shock, and in many a time, these can now be predicted. The rapid spread of coronavirus and the high case fatality rate has caught all the countries unawares. Never in the last few centuries economies around the world had come to a grinding halt, with human beings locked down in their houses.

This sudden interruption in economic and social interactions has propelled the state at the centre-stage of our life, which is a significant shift in the neoliberal world. Susan Strange (1996) had observed that with the rise of global corporations, the authority of the state and the trust on professional politicians and leaders had substantially declined, which led to the general erosion of territory-based authority and the rise of non-territorial, commercial authority. She called this process the "retreat of the state", locating herself within the discipline of International Relations. The "retreat of the state" also became a popular phrase to denote privatisation and contraction of public enterprises and welfare services during the neoliberal globalisation of economies. While the Financial Crisis of 2008 had required the intervention of the state in a specific sector, the COVID crisis has made the state omnipotent and omnipresent. The state has returned globally.

Swagato Sarkar

ssarkar@jgu.edu.in

1 OP Jindal Global University, Sonipat, India 
The debate around the world has concentrated on the extent of state interventions to provide healthcare services and to bailout the stressed economy, and on the trade-off between freedom-privacy and security with the expansion of control and surveillance of our bodies by the state. Concerns have been raised about the exclusion of marginalised peoples and people without insurance from accessing healthcare facilities, and the sacrifice of older people in the process of rational allocation of critical care. In this short essay, I will provide an outline of this debate. I will enquire what the pandemic control measures and outcomes tell us about the nature of the present Indian state, particularly how efficient it is in using the emergency power to enhance the state capacity.

\section{The global debate}

The debate on the state in the time of pandemic was, arguably, inaugurated by Giorgio Agamben (2020). Agamben argued that governments were using the pandemic as an opportunity to normalise a state of exception. The state of exception denotes the political condition of suspension of law and constitutional provisions, striping the legal rights of citizens and residents. Agamben claimed that the spread of coronavirus had provided an opportunity to the governments to instil fear, curtail movements, deny access to institutions, and suspend the activities of everyday life. As collective fear had gripped the society and the "desire for safety" had increased, a new regulatory regime had been established, limiting people's freedom. We were trading our experience of or demand for living a qualified form of political life (bios) for biological survival and reproductive life $(z o \bar{e})$. The state (or rather the sovereign) recognised us as biological beings, not rights-bearing citizens. Agamben apprehended that the administrative measures taken during the pandemic might normalise this paradigm of state of exception.

Byung-Chul Han (2020) argued that this new form of authoritarianism was located in the shifting paradigm of power (in Europe). During the Cold War, Europe had adopted the "immunological paradigm, which [was] based on the negativity of the enemy". ${ }^{1}$ The society had to be immunised from an external enemy or a threat. Europe had organised the society immunologically, "by living surrounded by borders and fences, which [prevented] the accelerated circulation of goods and capital". Globalisation had "suppressed all these immune thresholds to give capital free rein". The emergence of the "fatigue society" replaced the immunological paradigm. It was no longer based on the negativity of the external enemy, but "widespread promiscuity and permissiveness" and "the excess of positivity", which were "expressed as excess performance, excess production and excess communication". Correspondingly, "[repression] by others [gave] way to depression, exploitation by others [gave] way to voluntary self-exploitation and self-optimisation. In the performance society, one [was at war] above all against oneself". The COVID was the new external invisible and unknown enemy, which had forced the (European) governments to revert to the immunological paradigm by closing the borders, banning the entry of foreigners and reserving health facilities only for their citizens. Yet, these countries could not

\footnotetext{
${ }^{1}$ https://elpais.com/ideas/2020-03-21/la-emergencia-viral-y-el-mundo-de-manana-byung-chul-han-el-filos ofo-surcoreano-que-piensa-desde-berlin.html; English translation available at https://pianolaconalbedrio. wordpress.com/2020/03/29/the-viral-emergence-y-and-the-world-of-tomorrow-byun-chul-han/. All citations are from the English translation.
} 
control the spread of the virus and reduce the number of deaths. In contrast, the East Asian countries were relatively successful because they operated with a different logic of power.

The East Asian countries such as China, South Korea and Taiwan had extensively used technology to carry a massive number of tests, to trace and identify the infected persons and people they had been in contact with, and to isolate this group of people. The population was notified about infected persons in their vicinity. ${ }^{2}$ The digital surveillance infrastructure which these countries, particularly China, had created over the years allowed such technology-mediated interventions by the state. Han thought this digital surveillance was possible because, unlike Europe, privacy was not a political concern of these societies. There was no data protection in China, and the data flowed from the servers of the mobile and internet companies to the government. This technological connivance between the government and private companies made the users legible and visible to the government. The government would soon know the state of our bodily parameters such as temperature, blood sugar level, pressure, weight, etc. Along with the already available consumption data, it would create a new digital biopolitical regime. Han feared the successful use of digital surveillance in governing the society might prompt various governments to import the Chinese model of digital policing.

The continental literature on surveillance and biopolitics treats the population as a homogenous and anodyne mass, with no internal stratification and antagonisms, and the state as a monolithic entity. We cannot deny that the COVID crisis has made the state central in our everyday life, and the state has arrogated power to itself through laws and directives. However, we need to enquire what the state and governments have done with this absolute power, which can reveal the changing nature of the state.

\section{The Indian experience}

The Government of India invoked the Disaster Management Act, 2005 to designate the virus outbreak as a "disaster" and announced lockdown, imposing a curfew, prohibiting gathering of people, suspending transport, closing factories, and other activities. The sections of the Epidemic Diseases Act of 1897 were used to impose "social distancing" and isolation. Like the governments in various parts of the world, the central government adopted the war metaphor and hailed the medical professionals as "corona warriors". Lights and sound amplified the war cry and showered gratitude on these new soldiers. The spectacle of "janata curfew" (people's curfew), lighting lamps and beating utensils to produce sound ensured that the news of the virus reached every resident, creating both a public conscious about the virus and setting in the fear of socialisation. It seemed the people/janata were prepared for the war, whose frontier was their drawing room and the neighbourhood.

While the Western governments were indecisive in their initial response to the virus, the Indian government did not waste time mulling over the security-freedom trade-off. It imposed lockdown, which was widely believed to be the harshest in the world. The new scientifico-military governmentality was powerful enough to secure the authority of the state and displace the divine authority of the traditional deities of diseases. Unlike many

\footnotetext{
2 These made the use of technology for contact tracing popular worldwide, from Government of India's Arogya Setu app to Apple and Google's collaboration to create new application programming interfaces (APIs).
} 
other occasions, the people did not go to the babas, mandir or mazar to get remedy. While the pandemic of smallpox had given rise to Sitaladevi, no new deity for the eradication of coronavirus arose. The medicalisation of the diseased body and its submission to the apparatus of western/"scientific" and secular medicine with no resistance was arguably inaugurated during the anti-HIV AIDS campaign. It is safe to speculate that this process is now complete. During this COVID outbreak, except for a very few fringe elements, most of the people accepted the "scientific directives" of the state. The Ayurveda and home readies were not seen to provide a cure, but only to boost the immunity of the body. The claims of the Patanjali company that their Coronil kit could cure COVID was discredited by the same agencies which were otherwise sympathetic and had patronised this company. Coronil too became another immunity-boosting product. The indigenous resistance has been successfully quarantined within the threshold of a new immunity paradigm. Otherwise, the people have been told to wait for the vaccine, which again indicated the new hegemony of western medicine. There were neither protests to the central and state governments' policies nor any voice of dissent. The people and the opposition parties did not lodge any strong objection to these governmental measures and directives. Their silence could be read as tacit support to the government.

Various actions and measures announced by the Ministry of Home Affairs through regular directives have the imprint of classic Foucauldian and Deleuzian paradigms of power. The primary aim of these directives was to re-distribute the bodies in a given space through demarcation and segregation: a new form of zoning the city. In the absence of any medicine or treatment, the sole epistemic aim was to identify the infected bodies, which could then be isolated and quarantined in special wards, and deny the virus a host to survive and multiply, "breaking the chain". Hence, the initial slogan, "test, test, and test". One would have expected this identification process to be a secular one where bodies were indistinguishable from one another. However, the political imperative soon led to the search for the origin of the virus and the identity of the vector or super spreader of the virus. The virus was apparently of Chinese origin, and therefore a foreign invader and the Tablighi Jamaat of Delhi became the "super spreader" (vector). In this war against the virus, stricter the district administrations were in implementing the segregationist policy, the more they were valorised as role models. Bhilwara in Rajasthan and Agra in Uttar Pradesh were projected as early success stories.

In the beginning, it had seemed that this scientifico-military regime would manage the trajectory of the COVID-control measures. A new rule of expert seemed to have unfolded. Statistics, the old technology of modern power, came back with a vengeance, and immediately there were various graphs and projections. A new vocabulary of power emerged to make sense of the developing reality: "testing, tracing, isolation", "contact tracing", "doubling rate", "social distancing/do-gaaz ki doori", "flattening the curve", "quarantine", and so on. There were epidemiologists, economists, and doctors, who joined the statisticians and bureaucrats as the experts, offering advice, analysis, and opinion. This new rule of expert became visible and hegemonic. They were not isolated from the public view, but they were beyond the reach of any civil society organisations. The dominant caste groups did not challenge them. However, the experts could not become autonomous. The populist logic of Indian politics put a check to this new rule of experts.

In a two-part article, the journalists Nitin Sethi and Kumar Sambhav Shrivastava revealed that the Government of India had announced lockdown with no adequate healthcare and administrative preparation to contain and control the spread of the virus. It had ignored the recommendations of the panel of scientists it had formed. The scientists had advised increasing testing and quarantining facilities, and "community and civil society-led 
self-quarantine and self-monitoring". ${ }^{3}$ In another set of articles, the journalists Mridula Chari and Nitin Sethi reported that the government did "neither put in place the nationwide house-to-house surveillance mechanism nor [was] it following a "decision-making tree" suggested by the ICMR [Indian Council of Medical Research] to lift the lockdown". ${ }^{4}$ It had set certain "opaque parameters" to evaluate the effectiveness of the lockdown. ICMR, in turn, had maintained an inaccurate database of infection.

The government has attempted to prove that the lockdown was an effective measure and had been successful in controlling the outbreak. The populist imperative of projecting an image of a strong leader guided such attempts. The economists close to the ruling parties had written opinion pieces. They had tweeted how the measures of the government were flattening the curve and how India was winning the battle against COVID. This was a performance trap, to paraphrase Byung-Chul Han. Over the last few decades, particularly in the age of live television and social media, the government has been constructed as "something" which needs to be seen as active, continuously performing and working. A few acts and pronunciations are repeated around a set of conventions overtly and visibly. This performance trap has re-oriented the premise of government: "social contract" or constitution does not form the basis of government. A government needs to perform a set of actions and achieve specific goals. However, the sanctity and integrity of data, required to evaluate such actions and outcomes, are no longer deemed as values to be cherished and upheld. The present band of government experts are willing to fudge and suppress data to project the narrative of performance and achievement. ${ }^{5}$ It was this logic which had guided various actions of the central and the state governments in India, where the visibility of the activities of these governments was paramount.

Nevertheless, it was not ignoring the expert advice which has rattled the government. The stream of images of migrant workers returning to their native villages in eastern India on foot and in crammed trains from rest of India created a moral outrage. The trains arranged by the state to send back the workers from the metropolitan cities were inadequate and often lost their way in an unprecedented manner. The dormant civil society and opposition parties momentarily woke up and criticised the government, and a few made travel arrangements and provided food and water to these returning workers. In the absence of state intervention, temporary philanthropic activities provided a relief, which was an expression of power and benevolence. We could not be sure whether such actions would build long-term civic solidarity or those were a brief awakening of human kindness.

The government also took advantage of the ban on any social gathering to undertake a series of actions against the dissidents and the opponents across the country. Unlike the Black Lives Matter and associated protests in the USA, there was hardly any attempt at civil obedience in India to break the ban and protest such punitive actions. This again showed the gradual weakening of civil society vis-à-vis the state.

\footnotetext{
3 Nitin Sethi and Kumar Sambhav Shrivastava (2020) "Frustration in National Covid-19 Task Force", April 24, https://www.article-14.com/post/no-action-taken-frustration-in-national-covid-19-task-force.

4 Mridula Chari and Nitin Sethi (2020) "Cases Surged in Lockdown as Govt Ignored Experts", May 8, https://www.article-14.com/post/cases-surged-as-govt-ignored-scientific-advice-on-lifting-lockdown.

5 Refer to the NSSO employment data suppression: https://www.business-standard.com/article/economypolicy/unemployment-rate-at-five-decade-high-of-6-1-in-2017-18-nsso-survey-119013100053_1.html \& https://www.business-standard.com/article/pti-stories/108-economists-social-scientists-concerned-over-polit ical-interference-in-data-estimation-119031400979_1.html \& https://scroll.in/article/911442/the-daily-fixmodi-governments-moves-to-hide-official-statistics-greatly-damages-indian-democracy.
} 
With the prolonged closure of formal and informal economies, it was becoming clear that the impact of the lockdown would be adverse, pushing an already stagnant economy into recession and contraction. This problem was not uniquely Indian. The governments all over the world had to pay in full or part the wage liability of private firms and provide benefits to the people, both employed and unemployed. The central government in India responded to this economic crisis as if it were a supply-side problem with a liquidity crunch in the economy, ignoring the demand-side and solvency problems. It offered several types, and quantum, of loans to the beleaguered firms. There was no intervention to subsidise the income loss of both the firm-owners and workers. With the government hospital and health facilities in short supply, the middle- and upper-classes moved to the private healthcare systems, where they had to pay an exorbitant, and often an unjustified, amount.

Meanwhile, the virus, like an insurgent, broke through various spatial segregations and political ascriptions to make India the world's second most infected country, continually threatening to occupy the top spot.

\section{Coda}

What do the measures of pandemic control tell us about the Indian state? First, the Indian state is not concerned about the security-freedom trade-off. It can arrogate absolute power to itself and impose the will of a party elite and a group of ministers on the people. It can easily deploy the police force, but the other branches of the executive remain weak, which leads to the second issue: governance. Francis Fukuyama (2013) has defined governance as a government's ability to make and enforce rules and to deliver services. Governance focuses on the performance of the executive branch, which, at the hands of the neo-Weberian social scientists, narrowly means the performance of the bureaucracy. Instead of focusing on the bureaucracy, we should understand governance as the functional orientation of a government, its use of power and resources. In this respect, the brief history of COVIDcontrol in India and its consequences tells us that the capacity of the Indian state to govern the society has not improved. Scholars have argued that, on the one hand, the Indian state plays a central role in organising social and economic interests (Kaviraj 2000, Rudolph and Rudolph 1980). On the other hand, dominant castes and classes (i.e. dominant groups) have an enormous influence on the conduct of the states (Srinivas 1959). Informality permeates the systems of governance, developing various patron-client relationships, where the powerful patrons extract resources from the state (Bardhan 2003; Evans 1995). Yet, the dominant groups are fragmented, leading to the failure of collective action (Bardhan 2003). This process severely curtails the capacity of the state to intervene and implement policies effectively. Therefore, while it is easier to amass power by invoking emergency laws and displacing oppositional forces, but it is far more difficult to exercise that power prudently. The Indian state is adept at using its police and coercive power to create make-shift arrangements (e.g. temporary beds for COVID patients) to control a process and direct people to certain short-term behaviours (e.g. use of mask and hand sanitiser and maintaining social distance). Still, it fails or is inefficient in developing social infrastructure and long-term social change. Even when the bureaucracy becomes free from social control, it remains subservient to the political leadership ruling the country.

Third, if the fundamental character of the state has not changed, but the executive is insulated from social pressure, then it points to a new form of hegemony and decisionmaking apparatus. Ranajit Guha had argued that the articulation of power in India was 
"dominance without hegemony". He defined hegemony as "a condition of Dominance (D) such that, in the organic composition of D, Persuasion (P) [outweighed] Coercion (C)" and "hegemony [operated] as a dynamic concept and [kept] even the most persuasive structure of Dominance always and necessarily open to Resistance" (Guha 1998: 23, emphases in original). Dominance without hegemony is the condition when persuasion does not outweigh coercion, and the basis of power remains coercive. The exercise of power in the time of COVID has shown an anomaly: the state still needs to use its police power to control a pandemic, yet the people have submitted to the state without resistance. The people did so, not necessarily out of fear of the police, but because they reposed faith in the party elite and the group of ministers. Therefore, this is not a case of "dominance without hegemony", but dominance and hegemony. The people complain against inadequate economic measures for the workers and owners and the exorbitant cost of private healthcare. Yet, they accept surveillance and policing of their lives and participate in the cultural activities urged by political leadership. The pandemic has revealed a chasm between the economic and the cultural, with the state holding the middle ground and not allowing any form of resistance which can problematise and triangulate the two.

\section{References}

Agamben G (2020) The Invention of an Epidemic. https://www.journal-psychoanalysis.eu/coronavirus-andphilosophers/. Accessed 25 July 2020

Bardhan P (2003) The political economy of development in India. Oxford University Press, New Delhi

Evans PB (1995) Embedded autonomy: states and industrial transformation. Princeton University Press, Princeton

Fukuyama F (2013) Commentary. Governance 26:347-368. https://doi.org/10.1111/gove.12035

Guha R (1998) Dominance without Hegemony: History and Power in Colonial India. Harvard University Press, Cambridge, Mass

Han B-C (2020) The viral emergenc(e/y) and the world of tomorrow. https://pianolaconalbedrio.wordpress. com/2020/03/29/the-viral-emergence-y-and-the-world-of-tomorrow-byun-chul-han/. Accessed 15 July 2020

Kaviraj S (2000) The modern state. In: Hasan Z (ed) Politics and the state in India. Sage Publications, Delhi

Mridula C, Nitin S (2020) Cases surged in lockdown as govt ignored experts. 8 May. https://www.article-14. com/post/cases-surged-as-govt-ignored-scientific-advice-on-lifting-lockdown. Accessed 17 July 2020

Nitin S, Kumar SS (2020) Frustration in national covid-19 task force. 24 April. https://www.article-14.com/ post/no-action-taken-frustration-in-national-covid-19-task-force. Accessed 17 July 2020

Rudolph SH, Rudolph LI (1980) The centrist future of Indian politics. Asian Surv 20(6):575-594

Srinivas MN (1959) The dominant caste in Rampura. Am Anthropol 61

Strange S (1996) The Retreat of the State: The Diffusion of Power in the World Economy. Cambridge University Press, Cambridge

Publisher's Note Springer Nature remains neutral with regard to jurisdictional claims in published maps and institutional affiliations. 